\title{
Tracing the Geminivirus-Whitefly Transmission Pathway by Polymerase Chain Reaction in Whitefly Extracts, Saliva, Hemolymph, and Honeydew
}

\author{
Rosemarie C. Rosell, Ivone Torres-Jerez, and J. K. Brown
}

Department of Plant Sciences, University of Arizona, Tucson 85721.

Current address of R. C. Rosell: University of St. Thomas, Department of Biology, 3800 Montrose Blvd., Houston, TX 77006. Accepted for publication 19 November 1998.

\begin{abstract}
Rosell, R. C., Torres-Jerez, I., and Brown, J. K. 1999. Tracing the geminivirus-whitefly transmission pathway by polymerase chain reaction in whitefly extracts, saliva, hemolymph, and honeydew. Phytopathology 89: 239-246.

A membrane feeding system and polymerase chain reaction (PCR) were used to track squash leaf curl virus (SLCV) DNA in whole whitefly body extracts and in saliva, honeydew, and hemolymph of its whitefly vector, Bemisia tabaci, and a whitefly nonvector, Trialeurodes vaporariorum. SLCV ingestion was monitored by PCR in whiteflies that were given acquisition access periods (AAPs) ranging from 0.5 to $96 \mathrm{~h}$ on virus-infected plants. SLCV detection by PCR in whole body extracts was considered reflective of virus ingestion. As whiteflies were given longer AAPs, the number of whiteflies
\end{abstract}

ABSTRACT that ingested SLCV increased. SLCV DNA was detected in honeydew of vector and nonvector whiteflies, indicating that virions, viral DNA, or both passed unimpeded through the digestive system. SLCV DNA was detected in saliva and hemolymph of $B$. tabaci, but not in these fractions from nonvector whiteflies, despite virus ingestion by both. Although vector and nonvector whiteflies both ingested SLCV, only in the vector, B. tabaci, did virus cross the gut barrier, enter the hemolymph, or pass into the salivary system. These results suggest that digestive epithelia of nonvector whiteflies did not permit SLCV passage from the gut to hemocoel, whereas virus effectively crossed the analogous gut barrier in vector whiteflies.

Additional keywords: begomovirus, insect transmission, insect vector, persistent transmission, plant virus.
Whitefly-transmitted (WFT) geminiviruses, or begomoviruses, are placed in the family Geminiviridae $(31,36)$. Begomoviruses cause debilitating diseases of vegetable and fiber crops in the tropics and subtropics and, recently, have become problematic in temperate agroecosystems $(5,7-9,24,28)$. Diseases caused by WFT geminiviruses have been increasing since the mid-1970s, primarily due to increasing vector populations and their broadened distribution in subtropical and temperate agroecosystems $(7,9,25)$.

The Bemisia tabaci (Gennadius) group (11) contains the only known whitefly vectors of begomoviruses. These viruses are small, single-stranded DNA-containing plant viruses $(31,36)$. Geminivirus transmission is persistent and circulative in the whitefly vector, requiring an average latent period of 6 to $12 \mathrm{~h}$ prior to a transmission event $(5,20,21)$. The precise pathway of geminiviruses through their whitefly vector and the specific cellular and molecular barriers that virions traverse from ingestion to transmission are not known, nor is the molecular basis for the highly conserved specificity observed between $B$. tabaci and subgroup III geminiviruses. WFT geminiviruses are considered nonreplicative in their vector, and they are not passed transovarially $(34,36)$. In a recent report, however, transovarial transmission of tomato yellow leaf curl virus is shown in one population of B. tabaci (29), potentially altering the current model of the circulative nature of whitefly-mediated geminivirus transmission.

The majority of B. tabaci populations are polyphagous, colonizing a diverse suite of dicotyledonous, herbaceous plant species (19). Although most members of the B. tabaci group are capable of ingesting and transmitting geminiviruses to and from numerous host combinations, there are rare examples in which a geminivirus

Corresponding author: R. C. Rosell; E-mail address: rrosell@stthom.edu

Publication no. P-1999-0119-01R

(C) 1999 The American Phytopathological Society host range is restricted by the range of its $B$. tabaci vector $(2,4$, 11). Likewise, vector populations having broad host ranges, for example the B biotype (also B. argentifolii [3]), transmit many geminiviruses to diverse herbaceous plants. In these hosts, infection is limited primarily by the host range of the virus instead of the vector $(8,11,17)$.

The greenhouse whitefly, Trialeurodes vaporariorum (Westwood), is another whitefly taxon placed within the family Aleyrodidae (Homoptera: Hemiptera). Although it feeds in the phloem of dicotyledonous plants and has a host range in common with the most polyphagous of $B$. tabaci populations (44), the greenhouse whitefly is not a vector of geminiviruses $(9,28,40)$. However, it has been shown to be capable of ingesting geminivirus from virus-infected plants (40, this paper).

The nature of whitefly-geminivirus interactions is well characterized with respect to essential temporal transmission parameters. The requirements for successful geminivirus transmission have been examined for whiteflies that were given a range of acquisition (AAPs) and inoculation access periods (IAPs) $(5,15,20,22,23,28$, 34). Optimal experimental transmission is accomplished with a 12- to 24-h AAP and a 24- to 48-h IAP. A latent period of 4 to $12 \mathrm{~h}$ is required between initial ingestion and detectable transmission. There is no evidence that any whitefly-vector combination varies from this relative pattern, suggesting that the transmission pathway of a geminivirus is conserved for all subgroup III viruses because of specific cellular and molecular virus-vector interactions.

Squash leaf curl virus (SLCV) is a bipartite begomovirus that infects cucurbitaceous species in the Americas $(11,15,20)$. The biology and molecular biology of SLCV are well studied, and several strains are recognized $(12,15,20,36,40)$. A strain of SLCV first reported in Arizona in 1981, previously referred to as watermelon curly mottle $(12,15)$, has a wider host range compared with the type strain from California $(12,15,20)$. Referred to here as SLCV$\mathrm{AZ}$, this virus is experimentally transmissible by sap or biolistic 
inoculation, as well as by $B$. tabaci (15). The B biotype of $B$. tabaci, now the predominant whitefly vector in the United States, colonizes cucurbits (25) and transmits SLCV-AZ, providing a useful experimental system to investigate fundamental questions about geminivirus-whitefly vector interactions and the operative mechanisms in the transmission pathway.

Our working hypothesis is that specific capsid epitopes on SLCV virions interact with specialized sites in the whitefly vector. This hypothesis served as the basis for the development of the simulated transmission chamber and for its application to tracking geminivirus in the whitefly and the chamber fractions. Transmission characteristics of WFT geminiviruses mimic those of several wellstudied aphid-luteovirus systems in which interactions between viral capsid epitopes and membrane-binding sites or receptor-like molecules are thought to confer a circulative capability to virions (30). By analogy, the capsid proteins of geminiviruses are considered the most likely of viral-encoded proteins to be involved in similar cellular and molecular interactions with their vector, B. tabaci (34). In fact, the coat protein has been shown to be essential for vector-mediated transmission of geminiviruses $(1,6)$. Consequently, in nonvector species, the 'ingestion' of virions into the digestive system may be permissive, whereas the gut epithelia or other specialized anatomical features of the pathway delimit the virions' movement by preventing their entry into the hemolymph, hindering circulation in the hemolymph while en route to salivary system receptors, disallowing virion entry into the salivary glands, or all of the above.

In this study, we tracked SLCV-AZ in a whitefly vector and in a nonvector species capable of feeding on the same virus host plant by employing an artificial feeding system to simulate a range of AAP/IAP regimes and to better define the temporal and spatial association of virions with whiteflies. Polymerase chain reaction (PCR) (46) was used to detect SLCV DNA in single whiteflies fed in simulated transmission chambers after ingesting virus from infected plants and in the respective 'fractions' consisting of whitefly saliva, honeydew, and hemolymph. This approach permitted the precise, high-resolution tracking of geminivirus in vector and nonvector whiteflies in relation to a circulative model for transmission and the prospective sites of geminivirus-whitefly vector specificity. Preliminary results were published in abstract form $(42,43)$.

\section{MATERIALS AND METHODS}

Maintenance of whiteflies, virus culture, and plants. B. tabaci (B biotype) whiteflies were reared in colonies on cotton, Gossypium hirsutum L., a nonhost of SLCV. Whitefly colonies were maintained in a growth room at ambient temperature with a 16-h photoperiod. T. vaporariorum was reared in colonies on virus-free tobacco, Nicotiana tabacum L., and maintained in a greenhouse located several miles from the location of the $B$. tabaci colonies. Adult whiteflies were collected for experiments using a hand-held aspirator.

SLCV-AZ was obtained from field-infected watermelon plants in Yuma, AZ, and was transmitted to greenhouse-grown watermelon seedlings by mechanical inoculation (15). The SLCV-AZ culture was maintained, thereafter, by serial transfer to pumpkin plants, Cucurbita maxima Duschesne, alternately by sap (mechanical) inoculation (15), biolistic inoculation using total plant DNA extracts (16), or whitefly inoculation of two- to three-leaf stage, virus-free plants (12). Transmission was confirmed by characteristic symptom development occurring approximately 8 to 10 days postinoculation (PI) in the greenhouse or 6 to 8 days PI in a whitefly-free growth room $\left(16-\mathrm{h}\right.$ photoperiod, $\left.25^{\circ} \mathrm{C}\right)$. Healthy and virus-infected plants were used for whitefly AAPs at the three- to fourleaf stage and at 7 to 10 days PI. All whitefly acquisition and inoculation feeding periods were carried out on whole plants in insect-proof cages at 26 to $28^{\circ} \mathrm{C}$ with a $16 / 8$-h photoperiod.

Acquisition access time course experiments. Virus-free adult vector and nonvector whiteflies were allowed an AAP on healthy virus-free or SLCV-AZ-infected pumpkin plants for $0.5,2,4,8$, $12,24,48,72$, and $96 \mathrm{~h}$. Whiteflies were collected by aspiration and stored at $-80^{\circ} \mathrm{C}$. Twenty female vector and nonvector whiteflies were collected from virus-infected plants, and three to five female vector and nonvector whiteflies were obtained from healthy virus-free pumpkin plants for each AAP. Single female whiteflies from each AAP were extracted and assayed for SLCV by PCR. Experiments were replicated a minimum of three times for each AAP and each species of whitefly. The presence or absence of SLCV-AZ DNA in samples is reported as the mean of the three replicates and the standard error of the mean.

Simulated transmission experiments. A membrane feeding system, modified from Costa et al. (26), was used to simulate virus transmission. Chambers were made from $38-\mathrm{mm}$ petri dishes, rubber O-rings, and metal hair clips with the following changes. Stopcock grease was omitted, chambers were sealed with Parafilm around the periphery to prevent escape of whiteflies, and Parafilm was placed in the bottom of chambers to catch honeydew. All components used to assemble the chambers were surface-sterilized by UV irradiation immediately prior to use to reduce potential PCR contaminants. Filter-sterilized $25 \%$ sucrose ( $1 \mathrm{ml}$ per chamber) containing $0.01 \%$ green food coloring was provided as the feeding substrate. Green color was used as a phototactic attractant and to monitor whiteflies during feeding. Whiteflies were scored as 'active feeders' or 'nonfeeders' based upon the presence or absence, respectively, of a green coloration in the abdomen. When visible, green-colored honeydew was seen attached to the lingula or as droplets in the bottom of the chamber.

Virus-free whiteflies were collected from colonies by aspiration and allowed a 2-, 8-, 24-, or 48-h AAP on healthy or SLCV-AZinfected pumpkin. Fifty females plus fifty males were collected from test plants by aspiration, gently tapped into assembled feeding chambers, and allowed a 24-h IAP on sucrose feeding substrate.

Following each AAP/IAP regime, chambers were disassembled and live females that had ingested feeding substrate were collected with UV-irradiated brushes and stored in sterile microfuge tubes. Approximately $1 \mathrm{ml}$ of sucrose feeding substrate was collected using sterile graduated plastic pipettes and stored in sterile tubes. Honeydew was collected from the chamber floor by rinsing with $250 \mu \mathrm{l}$ of filter-sterilized $10 \mathrm{mM}$ Tris buffer containing $1 \mathrm{mM}$ EDTA (TE buffer; $\mathrm{pH}$ 8.0). Rinsates from chambers were transferred to separate sterile tubes using a sterile pipette. All fractions were held at $-20^{\circ} \mathrm{C}$, and frozen fractions were thawed immediately prior to DNA extraction and PCR.

For each AAP/IAP regime, eight feeding chambers were assembled: four contained whiteflies from virus-infected plants, two contained whiteflies from healthy plants, and two negative control chambers contained no whiteflies. PCR (described below) was conducted on the sucrose feeding substrate and the honeydew from each chamber and on five female whiteflies with green abdomens from each chamber. The experiments were carried out two times for both vector and nonvector whiteflies and for each AAP/IAP regime.

Hemolymph collection and SLCV detection. Adult whiteflies were collected by aspiration from healthy virus-free and virus-infected pumpkin plants and immediately cooled to $-20^{\circ} \mathrm{C}$ to arrest movement. Female whiteflies were attached, dorsal side up, to UV-irradiated Parafilm using a fast-drying glue (Ted Pella, Inc., Redding, CA) and covered with fresh mineral oil. A hemolymph droplet was forced from an immersed individual by removal of a hindwing with a sterile 28-gauge insulin needle, causing the whitefly to "bleed" a drop of hemolymph into the mineral oil. The hemolymph droplet was collected using a sterile, glass, 1 - to 5- $\mu$ l capillary pipette drawn to a fine point of $\sim 0.5 \mu \mathrm{m}$ in diameter. Hemolymph ( $\sim 10$ to $50 \mathrm{nl}$ per whitefly) was immediately transferred to a tube containing $50 \mu \mathrm{l}$ of sterile TE buffer (pH 8.0) and $10 \mathrm{mM}$ phenylmethyl sulfonyl fluoride (Sigma Chemical Co., St. Louis) to prevent coagulation.

Virus-free adult B. tabaci whiteflies were allowed AAPs of 0.5, $2,4,8,12,24,48,72$, or $96 \mathrm{~h}$ on either healthy or SLCV-AZ-in- 
fected pumpkin plants. Virus-free adult $T$. vaporariorum were given AAPs of 2, 12, 24, or $96 \mathrm{~h}$ on analogous test plants. Vector and nonvector whiteflies were collected from plants after each AAP. Hemolymph was collected from each of 10 females exposed to virus-infected plants and from each of 3 to 5 females permitted to feed on healthy virus-free plants for each AAP tested. PCR was conducted on hemolymph collected at each time interval, and experiments were replicated three times for vector and nonvector whiteflies at each AAP. Presence or absence of SLCV-AZ DNA is reported as the mean of three replicates and the calculated standard error of the mean.

Extraction of SLCV-AZ DNA. Total nucleic acids was extracted from single female whitefly by grinding in cold $\left(4^{\circ} \mathrm{C}\right)$ lysis buffer (5 mM Tris-HCl, 0.5 mM EDTA, 0.5\% Nonidet P-40 [Sigma Chemical Co., St. Louis], and $1 \mathrm{mg}$ of proteinase $\mathrm{K}$ per ml, $\mathrm{pH}$ 8.0). Samples were incubated at $65^{\circ} \mathrm{C}$ for $15 \mathrm{~min}$ and at $95^{\circ} \mathrm{C}$ for $10 \mathrm{~min}$, centrifuged briefly, and held at $4^{\circ} \mathrm{C}$ until assayed by PCR.

DNA was extracted from the sucrose feeding substrate after the addition of filter-sterilized TE buffer ( $\mathrm{pH}$ 8.0) to yield a final concentration of $10 \%$ sucrose. Samples were brought to a final concentration of $3 \%$ sodium dodecyl sulfate (SDS) with $20 \%$ stock SDS, incubated at $65^{\circ} \mathrm{C}$ for $15 \mathrm{~min}$ and at $95^{\circ} \mathrm{C}$ for $5 \mathrm{~min}$, cooled to room temperature, and extracted with phenol/chloroform (1:1). Samples were mixed by gentle vortexing, and phase separation was by microcentrifugation at $16,000 \times g$ for $5 \mathrm{~min}$. The aqueous phase was collected and nucleic acids ethanol-precipitated overnight at $-20^{\circ} \mathrm{C}$. Total nucleic acids were pelleted by centrifugation and dissolved in $5 \mu \mathrm{l}$ of double-distilled water immediately before PCR. DNA extracts from honeydew and hemolymph were prepared as described for sucrose substrate, but the initial dilution step was omitted.

Detection of SLCV-AZ DNA by PCR. PCR assays were conducted with $5 \mu \mathrm{l}$ of each template DNA in a total reaction volume of $25 \mu \mathrm{l}$ as described (46). PCR primers were degenerate primers that permit detection of subgroup III geminiviruses by annealing to sequences that flank the conserved core region of the coat protein gene (core $\mathrm{Cp}$ ), yielding a diagnostic $~ 565$-bp virus fragment (46). Experimental controls were a PCR master mix in which the template DNA was $1 \mu \mathrm{l}$ of SLCV-AZ-infected pumpkin DNA or $1 \mu \mathrm{l}$ of healthy pumpkin DNA, and $2 \mu \mathrm{l}$ of TE buffer and $2 \mu \mathrm{l}$ of doubledistilled water. PCR products were analyzed by agarose gel electrophoresis as previously described (46).

Southern hybridization. PCR products were analyzed by Southern hybridization to confirm the geminivirus identity of the diagnostic 565-bp product. A core Cp amplicon obtained from SLCVAZ DNA extracts was cloned into pCR2.1 plasmid (TA cloning kit; Invitrogen, Carlsbad, CA). Its identity as a SLCV core Cp clone was confirmed by automated DNA sequencing and direct comparison with the analogous core $\mathrm{Cp}$ gene sequence of SLCV-E, obtained from GenBank accession no. M38183 (37). The SLCV-AZ core $\mathrm{Cp}$ hybridization probe was constructed by first amplifying a PCR product from the core $\mathrm{Cp}$ clone to obtain the expected-size amplicon. This 565-bp amplicon was purified from the gel and used as the template in a second reaction in which the probe was labeled by PCR incorporation of digoxigenin-dUTP (Boehringer Mannheim Biochemicals, Indianapolis, IN). The first PCR reaction mixture $(25 \mu \mathrm{l})$ contained $100 \mathrm{ng}$ of the cloned SLCV core fragment as the PCR template, $0.15 \mathrm{mM}$ dNTPs, $2.5 \mathrm{mM} \mathrm{MgCl}$, 0.75 units of $T a q$ polymerase, and $20 \mu \mathrm{M}$ of each core Cp primer. Parameters for the second PCR reaction were identical, except that the gel-purified amplicon was used as the template and dUTP was added to a final concentration of $0.005 \mathrm{mM}$ digoxigenindUTP. Digoxigenin-labeled probes contained approximately $5 \%$ labeled bases.

PCR products were fractionated by electrophoresis in $1.2 \%$ agarose and transferred by capillary diffusion to Hybond N+-charged, nylon membranes (Amersham Corp., Arlington Heights, IL) and UV-cross-linked for $20 \mathrm{~min}$. According to the manufacturer's directions (Boehringer Mannheim Biochemicals), blots were prehybridized at $65^{\circ} \mathrm{C}$ for $1 \mathrm{~h}$ and hybridized with labeled probe (at $200 \mathrm{ng} / \mathrm{ml}$ hybridization solution) overnight at $65^{\circ} \mathrm{C}$. Probe detection was carried out according to the manufacturer's recommendation using an antidigoxigenin antibody and alkaline phosphatase detection system (Boehringer Mannheim Biochemicals).

\section{RESULTS}

Temporal monitoring of SLCV-AZ in whitefly extracts. SLCV DNA was readily detectable in whole body extracts of single female B. tabaci and T. vaporariorum that were permitted prior acquisition access to SLCV-AZ-infected pumpkin (Figs. 1 to 3). These results were based upon the presence or absence of the diagnostic 565-bp core $\mathrm{Cp}$ fragment and upon Southern hybridization with a SLCV core Cp probe (Figs. 1 and 2). No virus-specific PCR product was obtained from DNA extracts of whiteflies that were allowed equivalent AAPs on healthy virus-free plants (Figs. 1 and 2 ). The 565-bp geminivirus PCR product was consistently amplified and detected in total DNA extracts of positive-control, SLCVAZ-infected plants, but not in healthy plant extracts or in PCR controls to which no DNA template was added (Figs. 1 and 2).

SLCV DNA was detectable in approximately $10 \%$ of individual B. tabaci and T. vaporariorum that were given an AAP as brief as $0.5 \mathrm{~h}$ on virus-infected plants (Fig. 3). When B. tabaci females were allowed AAPs on SLCV-infected pumpkin, PCR-positive individuals increased from $10 \%$ to greater than $90 \%$ between a 0.5 - to 12 -h AAP, decreased to $\sim 60 \%$ following a $24-$ to 48 -h AAP, and increased to $90 \%$ or greater after a $96-\mathrm{h}$ AAP. In contrast, the frequency of virus detection in single nonvector female whiteflies increased from $10 \%$ to greater than $90 \%$ between 0.5 to $24 \mathrm{~h}$, and then remained at greater than $95 \%$ from 48- to 96-h AAP. In relation to the shorter and longer AAP regimes tested, we consistently noted a decreased frequency of virus detection in B. tabaci after a 24-h AAP, while a similar decrease in detection frequency was never observed following the initial rise in detection frequency for female T. vaporariorum.

Simulated virus transmission. The potential for geminivirus transmission was evaluated using whiteflies that were provided a range of AAPs on healthy control or SLCV-infected plants followed by a 24-h IAP in membrane feeding chambers. With a 2-h AAP on SLCV source plants and a 24-h IAP in simulated transmission chambers, virus DNA was detected in whole body extracts of B. tabaci, but not in feeding substrate containing whitefly saliva and salivary products or in honeydew produced by feeding whiteflies (Table 1). However, after an 8-h AAP/24-h IAP regime, virus was detected in single whiteflies, sucrose substrate, and honeydew (Table 1, Fig. 4). Similar results were obtained with whole body extracts and chamber fractions from the 24-h AAP/24-h IAP and 48-h AAP/24-h IAP regimes (Table 1). In contrast, PCR detection of viral DNA in $T$. vaporariorum, allowed analogous AAP/IAPs on virus-infected plants and in chambers, differed. Virus DNA was detectable in nonvector whole body extracts and excreted honeydew, but virus DNA was never detected in sucrose feeding substrate (Table 1, Fig. 5). SLCV DNA was also never detected in whole body extracts, feeding substrate, or honeydew from vector or nonvector whiteflies that were provided the same AAPs on virus-free pumpkin followed by a 24-h IAP in feeding chambers. Virus DNA was not detected in sucrose substrate or in "honeydew" fractions (chamber rinsate) collected from chambers to which whiteflies were not introduced. The same results were obtained in both replicates of the experiment.

Results of control transmission bioassays conducted with vector and nonvector whiteflies using a 48-h AAP on SLCV-infected source plants, followed by transfer to pumpkin for a 48-h IAP (to overcome the latent period), corroborated results obtained from analysis of sucrose fractions (data not shown). B. tabaci transmitted SLCV from pumpkin to pumpkin 70 to $100 \%$ of the time, but transmission by the nonvector whitefly did not occur at any AAP/IAP. 
Results of PCR and Southern hybridization indicated that the diagnostic PCR products amplified from vector whiteflies, feeding substrate, and honeydew fractions from feeding chambers at the various AAPs consistently hybridized to the SLCV probe (Fig. 4;
Southern hybridization data not shown). However, only PCR product from whiteflies and honeydew fractions from nonvector whiteflies that were given identical AAP/IAP regimes on SLCV-infected plants hybridized with the viral DNA probe (Fig. 5; Southern hy-
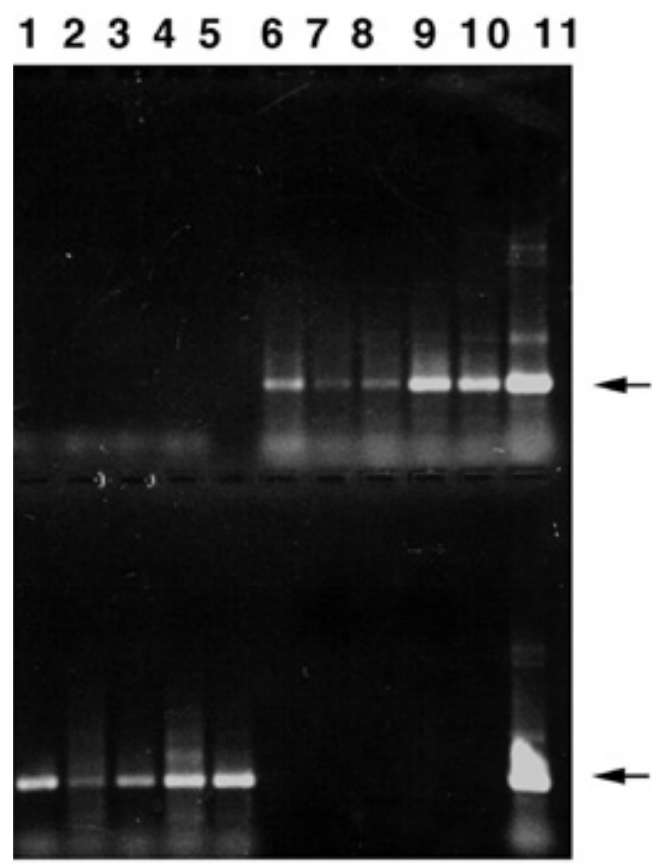

12234556678091011

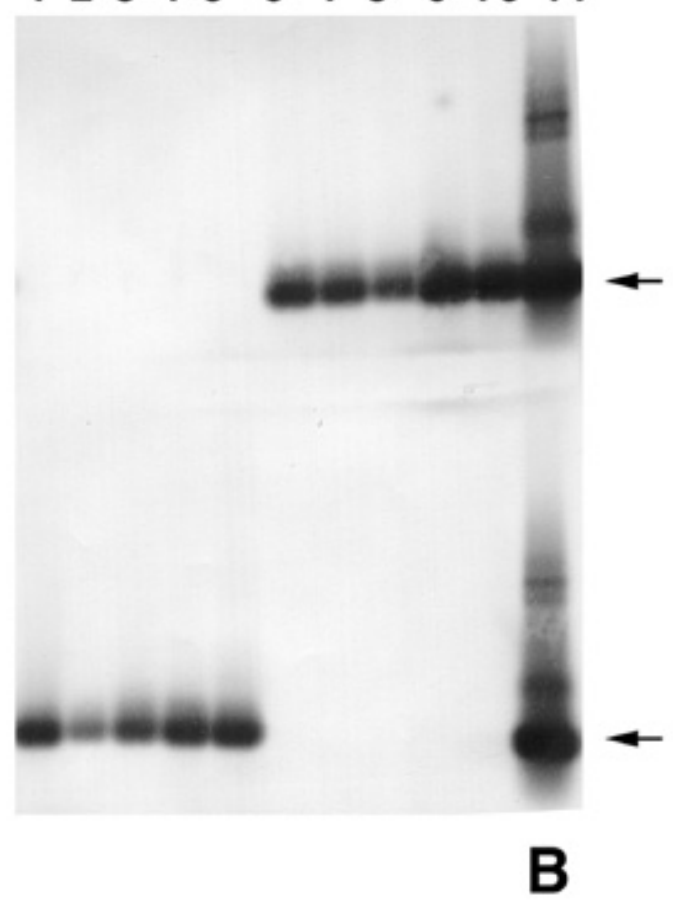

Fig. 1. A, Lanes 1 to 5 bottom and lanes 6 to 10 top, Representative agarose gel from temporal monitoring of squash leaf curl virus Arizona strain (SLCV-AZ) in whitefly extract experiments showing polymerase chain reaction (PCR) products from individual female Bemisia tabaci that were given a 72-h acquisition access period (AAP) on SLCV-infected pumpkin. Arrows indicate a SLCV-specific 565-bp DNA fragment. In this replicate, 80\% of individuals from SLCVinfected pumpkin were positive for detectable levels of geminivirus (10 individuals not shown). Lanes 2 to 4 top, No analogous PCR product was present in whiteflies given a 72-h AAP on healthy pumpkin. Lane 7 bottom, No DNA template (negative control). Lane 9 bottom, DNA extracted from healthy pumpkin (negative control). Lane 11 top and bottom, DNA extracted from SLCV-infected pumpkin (positive control). B, Representative Southern blot hybridization of agarose gel in $\mathbf{A}$ (lanes in the same order) using cloned SLCV-AZ core coat protein gene as the digoxigenin-labeled probe.
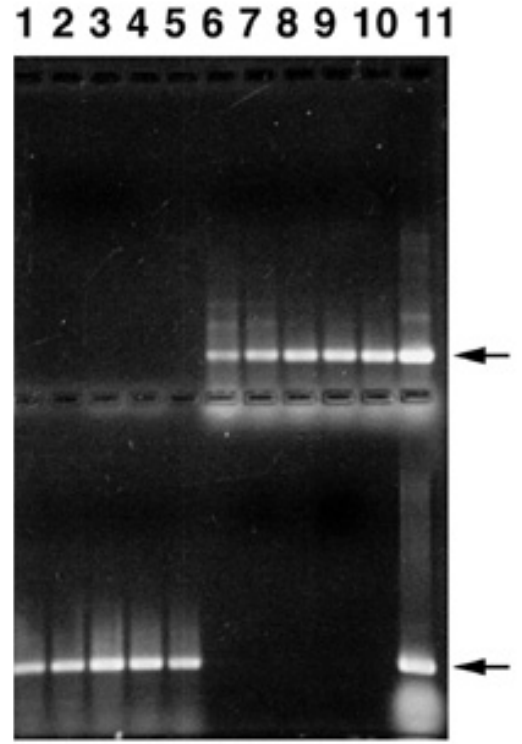

A

\section{1}

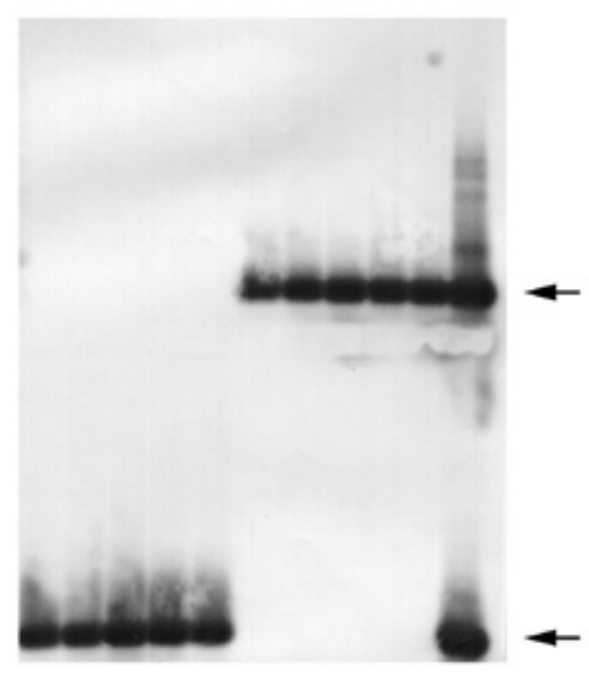

B

Fig. 2. A, Lanes 1 to 5 bottom and lanes 6 to 10 top, Representative agarose gel from acquisition access time course experiments showing polymerase chain reaction (PCR) products from single Trialeurodes vaporariorum whiteflies that were given a 72-h acquisition access period (AAP) on squash leaf curl virus (SLCV)-infected pumpkin. Arrows indicate a SLCV-specific 565-bp DNA fragment. In this replicate, 90\% of individuals from SLCV-infected pumpkin were positive for detectable levels of geminivirus (10 individuals not shown). Lanes 2 to 4 top, No analogous PCR product was present in whiteflies that were given a 72-h AAP on healthy pumpkin. Lane 7 bottom, no DNA template (negative control). Lane 9 bottom, DNA extracted from healthy pumpkin (negative control). Lane 11 top and bottom, DNA extracted from SLCV-infected pumpkin (positive control). B, Representative Southern blot hybridization of agarose gel in A (lanes in the same order) using cloned SLCV-AZ core coat protein gene as the digoxigenin-labeled probe. 
bridization data not shown). No diagnostic PCR product or DNA hybridization was observed for vector or nonvector whiteflies that were allowed access to healthy control plants; nor was virus detected in feeding substrate or honeydew collected from control chambers (Figs. 3 and 4; Southern hybridization data not shown). Positive hybridization was also observed for several larger fragments obtained from PCR amplification of extracts from whole whiteflies, chambers, and plant extracts (Southern hybridization data not shown). However, this label was not observed in lanes containing PCR reaction products from any whiteflies that were given access to healthy plants or from feeding substrate or honeydew fractions (Figs. 4 and 5). These larger fragments appeared to be multimers of the 565-bp PCR product that were routinely amplified at low background levels, but they were not detected by the lower resolution ethidium bromide-staining used for routine detection. Multimers are known to form, at times, as the result of excessive secondary structure within PCR target sequences that favor heteroduplex formation (45).

Hemolymph collection and analysis. SLCV-AZ DNA was not detectable by PCR in hemolymph of B. tabaci that were allowed a 0.5-h AAP on virus-infected plants (Fig. 6). However, virus was detected in hemolymph of individual vector whiteflies that were given an AAP of at least $2 \mathrm{~h}$. In vector whiteflies that were given access to virus-infected plants, the frequency of individuals with viral DNA detectable in hemolymph increased from 0 to $85 \%$ with AAPs of 0.5 to $12 \mathrm{~h}$, stabilized at about $90 \%$ with AAPs of 24 and $48 \mathrm{~h}$, and decreased to 80 to $85 \%$ for AAPs of 72 and $96 \mathrm{~h}$ (Figs. 6 and 7). In contrast, SLCV was never detected in hemolymph of the nonvector at any AAP tested (Figs. 6 and 7) or in hemolymph

TABLE 1. Polymerase chain reaction-based virus detection in vector and nonvector whole body extracts and in feeding substrate and honeydew from chambers following simulated transmission events

\begin{tabular}{|c|c|c|c|c|}
\hline & \multicolumn{4}{|c|}{ AAP/IAP } \\
\hline & $2 / 24$ & $8 / 24$ & $24 / 24$ & $48 / 48$ \\
\hline \multicolumn{5}{|l|}{ Bemisia tabaci } \\
\hline \multicolumn{5}{|c|}{ Infected pumpkin - replicate 1} \\
\hline Substrate & $0 / 4^{\mathrm{b}}$ & $4 / 4$ & $4 / 4$ & $4 / 4$ \\
\hline Honeydew & $0 / 4$ & $4 / 4$ & $4 / 4$ & $4 / 4$ \\
\hline Whiteflies & $4 / 4$ & $4 / 4$ & $4 / 4$ & $4 / 4$ \\
\hline \multicolumn{5}{|c|}{ Infected pumpkin - replicate 2} \\
\hline Substrate & $0 / 4$ & $4 / 4$ & $4 / 4$ & $4 / 4$ \\
\hline Honeydew & $0 / 4$ & $4 / 4$ & $4 / 4$ & $4 / 4$ \\
\hline Whiteflies & $2 / 4$ & $4 / 4$ & $4 / 4$ & $4 / 4$ \\
\hline \multicolumn{5}{|c|}{ Healthy pumpkin ${ }^{c}$} \\
\hline Substrate & $0 / 2$ & $0 / 2$ & $0 / 2$ & $0 / 2$ \\
\hline Honeydew & $0 / 2$ & $0 / 2$ & $0 / 2$ & $0 / 2$ \\
\hline Whiteflies & $0 / 2$ & $0 / 2$ & $0 / 2$ & $0 / 2$ \\
\hline \multicolumn{5}{|c|}{ No whitefly negative controls ${ }^{c}$} \\
\hline Substrate & $0 / 2$ & $0 / 2$ & $0 / 2$ & $0 / 2$ \\
\hline Honeydew & $0 / 2$ & $0 / 2$ & $0 / 2$ & $0 / 2$ \\
\hline \multicolumn{5}{|c|}{ Trialeurodes vaporariorum } \\
\hline \multicolumn{5}{|c|}{ Infected pumpkin - replicate 1} \\
\hline Substrate & $0 / 4$ & $0 / 4$ & $0 / 4$ & $0 / 4$ \\
\hline Honeydew & $0 / 4$ & $4 / 4$ & $4 / 4$ & $4 / 4$ \\
\hline Whiteflies & $4 / 4$ & $4 / 4$ & $4 / 4$ & $4 / 4$ \\
\hline \multicolumn{5}{|c|}{ Infected pumpkin - replicate 2} \\
\hline Substrate & $0 / 4$ & $0 / 4$ & $0 / 4$ & $0 / 4$ \\
\hline Honeydew & $0 / 4$ & $4 / 4$ & $4 / 4$ & $4 / 4$ \\
\hline Whiteflies & $4 / 4$ & $4 / 4$ & $4 / 4$ & $4 / 4$ \\
\hline \multicolumn{5}{|c|}{ Healthy pumpkin ${ }^{c}$} \\
\hline Substrate & $0 / 2$ & $0 / 2$ & $0 / 2$ & $0 / 2$ \\
\hline Honeydew & $0 / 2$ & $0 / 2$ & $0 / 2$ & $0 / 2$ \\
\hline Whiteflies & $0 / 2$ & $0 / 2$ & $0 / 2$ & $0 / 2$ \\
\hline \multicolumn{5}{|c|}{ No whitefly negative controls ${ }^{c}$} \\
\hline Substrate & $0 / 2$ & $0 / 2$ & $0 / 2$ & $0 / 2$ \\
\hline Honeydew & $0 / 2$ & $0 / 2$ & $0 / 2$ & $0 / 2$ \\
\hline
\end{tabular}

${ }^{\text {a }} \mathrm{AAP} / \mathrm{IAP}=$ acquisition access period/inoculation access period in hours.

b Data reported as number of chambers with detectable viral DNA/number of chambers tested.

c Data the same for two replicates.

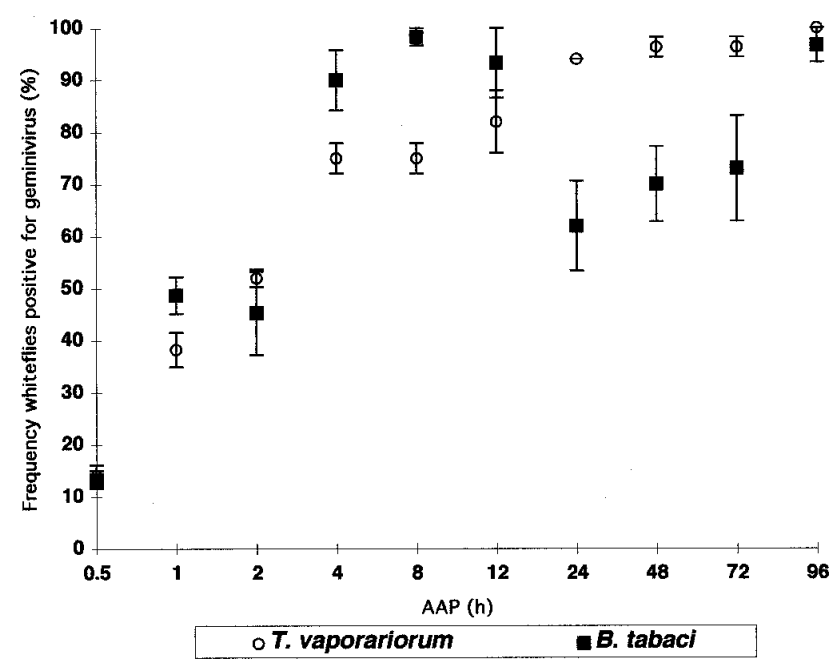

Fig. 3. Polymerase chain reaction-based detection of squash leaf curl virus Arizona strain (SLCV-AZ) DNA in individual whiteflies that were given various acquisition access periods (AAPs) on virus-infected plants. The frequency (percent) of Bemisia tabaci and Trialeurodes vaporariorum females with detectable levels of SLCV-AZ DNA is shown as the mean of three replicates with the standard error of the mean indicated by error bars. Control whiteflies that were allowed AAPs on healthy plants had no detectable virus DNA and thus are not shown.

\section{$\begin{array}{llllllllllll}1 & 2 & 3 & 4 & 5 & 6 & 7 & 8 & 9 & 10 & 11 & 12\end{array}$}

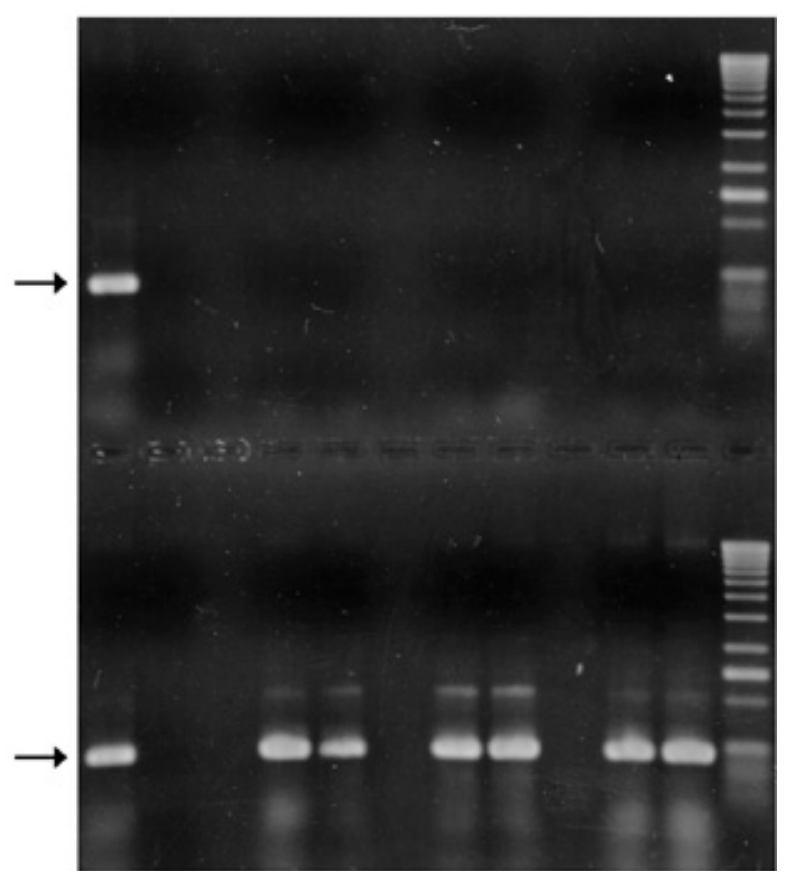

Fig. 4. Representative agarose gel from a simulated transmission experiment showing polymerase chain reaction products from Bemisia tabaci whiteflies that were given an 8-h acquisition access period (AAP) on either squash leaf curl virus (SLCV)-infected or healthy pumpkin followed by a $24-h$ inoculation access period (IAP) on sucrose in simulated transmission chambers. From the chambers containing whiteflies that were given access to virus source, the 565-bp DNA fragments (arrows) indicated the presence of SLCV-AZ (Arizona strain) DNA in the whiteflies (lanes 4 and 5 bottom), the honeydew (lanes 7 and 8 bottom), and the feeding substrate (lanes 10 and 11 bottom). No analogous DNA products are seen in the whiteflies from virus-free pumpkin that were given an 8-h AAP/24-h IAP (lanes 4 and 5 top), the honeydew (lanes 7 and 8 top), or the feeding substrate (lanes 10 and 11 top). Lane 1, SLCV DNA extracted from virus-infected pumpkin (positive control); lane 2, no DNA template (negative control); and lane 12, DNA 100-kb ladder. 
from vector or nonvector whiteflies that were given access to virusfree pumpkin control plants (Fig. 7). Southern hybridization results corroborated these data in that the virus-specific probe hybridized strongly to the diagnostic 565-bp PCR product obtained from hemolymph fractions of vector whiteflies that were provided access to feeding on virus-infected plants (data not shown). Furthermore, hemolymph fractions from nonvector whiteflies that were given AAPs on virus-infected plants were negative by Southern hybridization at all time periods tested, and virus was never detected by

\section{$\begin{array}{llllllllllll}1 & 2 & 3 & 4 & 5 & 6 & 7 & 8 & 9 & 10 & 11 & 12\end{array}$}

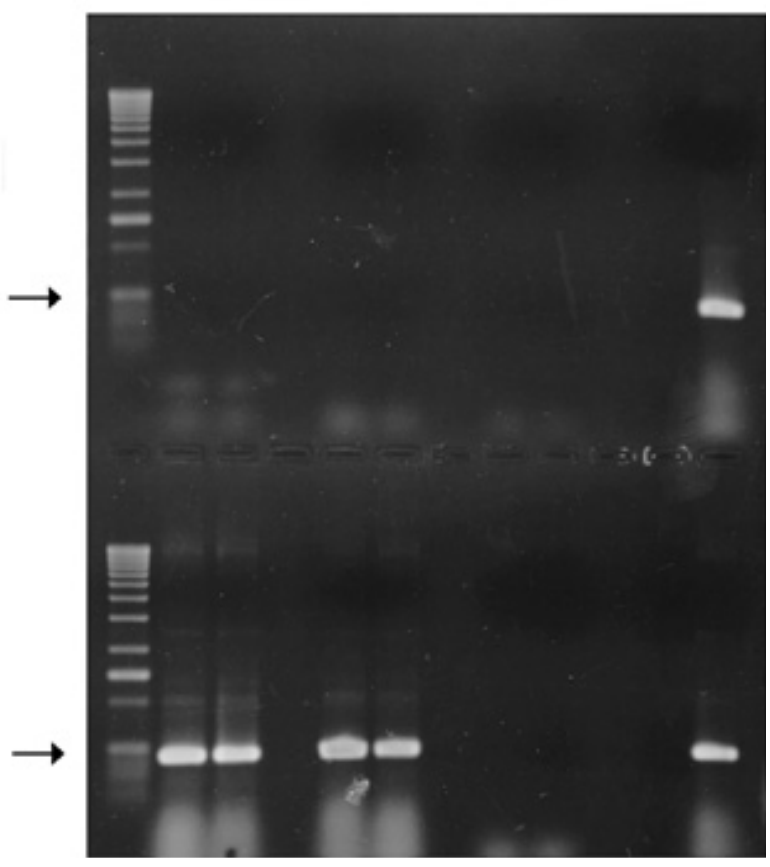

Fig. 5. Representative agarose gel from simulated transmission experiments with nonvector Trialeurodes vaporariorum showing polymerase chain reaction results from whiteflies that were given an 8-h acquisition access period (AAP) on either squash leaf curl virus (SLCV)-infected or healthy pumpkin followed by a 24-h inoculation access period (IAP) on sucrose in simulated transmission chambers. Virus-specific 565-bp products (arrows) indicate the presence of SLCV-AZ (Arizona strain) DNA in whiteflies that were given access to SLCV-infected pumpkin (lanes 2 and 3 bottom) and their honeydew (lanes 5 and 6 bottom). No analogous products were present in the feeding substrate (lanes 8 and 9 bottom) from the same chamber. Also negative were the whiteflies (lanes 2 and 3 top), honeydew (lanes 5 and 6 top), and feeding substrate (lanes 8 and 9 top) from chambers in which whiteflies were given an 8-h AAP on virus-free pumpkin. Lane 1, DNA 100-kb ladder; lane 11, no DNA template (negative control); and lane 12, SLCV DNA extracted from virus-infected pumpkin (positive control).

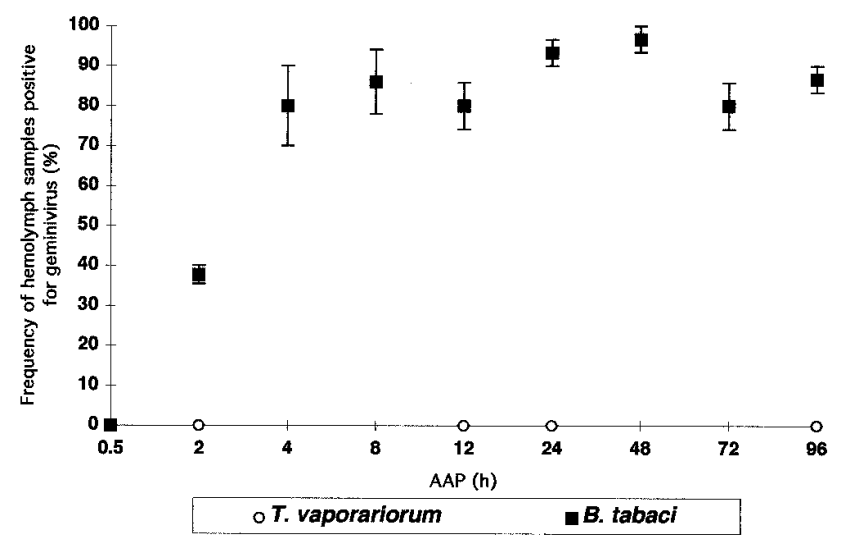

Fig. 6. Polymerase chain reaction detection of squash leaf curl virus DNA in hemolymph of vector and nonvector whiteflies that were allowed various acquisition access periods (AAPs) on virus-infected plants. Bars = standard error of the mean of three replicates.
DNA hybridization in vector or nonvector whiteflies that were given various AAPs on virus-free plants (data not shown).

\section{DISCUSSION}

The application of PCR to the detection of geminiviruses has gained prominence as a sensitive assay method for tracking geminiviruses in plants and their whitefly vectors $(10,27,29,38,41,46)$. Enzyme-linked immunosorbent assay and squash-blot with DNA hybridization have also been used for similar purposes; however, they typically yield inconsistent results with single insects (40). The PCR primers used in this study are highly specific in directing the amplification of the core region of the core $\mathrm{Cp}$ of only subgroup III geminiviruses (46). Coupled with the detection of PCR products by DNA hybridization with a PCR-labeled virus probe, this permits the extremely high-resolution detection of geminiviruses required for tracking virus DNA in single whiteflies and in minute volumes of whitefly-derived 'fractions' from simulated transmission chambers. However, positive virus detection, which only indicates virus ingestion, does not necessarily lead to transmission. As demonstrated here and elsewhere (40), geminivirus can be detected in the nonvector $T$. vaporariorum, although transmission assays consistently yield negative results. Consequently, the results of assays in which virus is detected in the insect, in the absence of transmission bioassay, provide insufficient proof of vectoring capacity. These data indicate that there may be additional virus-insect combinations in which ingestion, but not transmission, results from insects feeding on virus-infected plants.

We detected SLCV DNA in whole body extracts of both vector and nonvector whiteflies that were given an AAP as brief as $0.5 \mathrm{~h}$, and PCR detection frequencies increased accordingly when white-

\section{2}

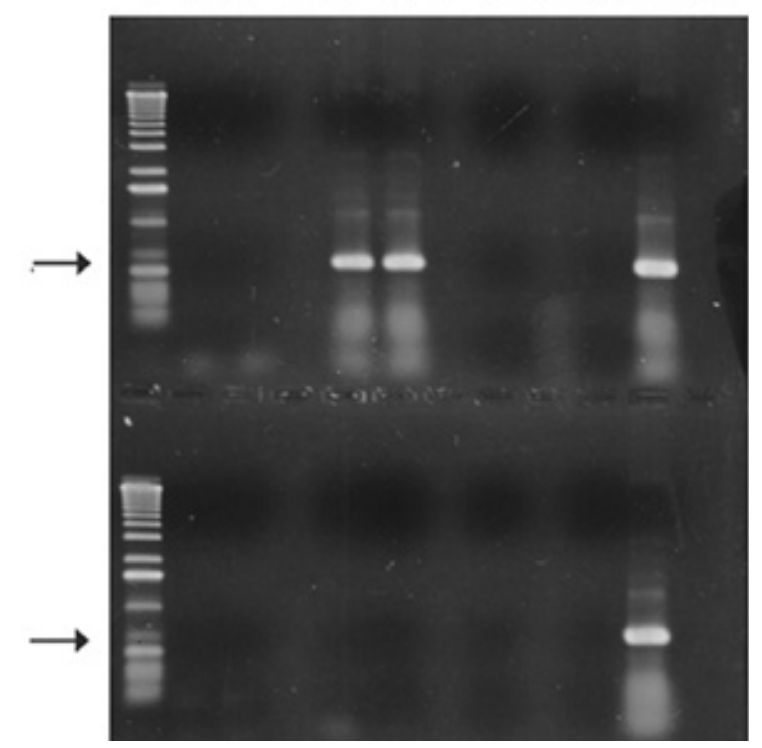

Fig. 7. Representative agarose gel showing polymerase chain reaction products from individual vector and nonvector hemolymph samples. Whiteflies were allowed a 48-h acquisition access period (AAP) on either virus-free pumpkins or on squash leaf curl virus (SLCV)-infected pumpkins. Positive detection of 565-bp DNA fragments (arrows) indicates the presence of SLCV-AZ (Arizona strain) DNA in hemolymph from individual Bemisia tabaci females given access to virus-infected plants (lanes 5 and 6 top). Viral DNA was never detectable in hemolymph samples from individuals that were allowed a 48-h AAP on healthy pumpkin (lanes 2 and 3 top). The virus-specific 565-bp product was not detectable in hemolymph from Trialeurodes vaporarorium whiteflies that were given access to virus-infected plants (lanes 5 and 6 bottom). Neither were any analogous products seen in hemolymph samples from nonvector whiteflies that fed on healthy pumpkin (lanes 2 and 3 bottom). Lane 1, 100-kb DNA ladder; lane 8, no DNA template (negative control); lane 9, DNA extracted from healthy pumpkin (negative control); and lane 11, DNA extracted from SLCV-infected pumpkin (positive control). 
flies were given longer AAPs. A comparison of PCR detection of geminivirus DNA in $B$. tabaci to geminivirus transmission efficiencies determined by transmission bioassay $(13,14,20,22)$ indicated similar trends. In general, the greater the duration of the AAP, the higher the PCR detection rate and the higher the transmission rate with most AAP/IAP regimes examined (20,22). However, our observation that both the detection of SLCV and the transmission frequencies moderately decreased between the 12- and 24-h AAP and increased again after a 72-h AAP is corroborated with transmission frequencies of cotton leaf crumple virus examined at these same AAP/IAP regimes (13). This may be reflective of the duration of the latent period; however, the precise biological significance remains to be investigated.

Simulated transmission experiments indicated that B. tabaci, but not $T$. vaporariorum, passed SLCV through the alimentary canal into the hemocoel and into the salivary system. Detectable quantities of viral DNA were eliminated from the alimentary canal of whitefly in the honeydew excrement, indicating that not all geminivirus ingested was transmitted or was not transmissible. One drawback to using PCR for tracking virus is that virions cannot be distinguished from naked viral DNA forms, which are also present in phloem sap. Nonetheless, these results suggest that whiteflies lack generalized DNase or protease activity in the lumen of the digestive system, leading to detectable viral DNA in the honeydew, irrespective of its origin (virions or unencapsidated singlestranded or double-stranded DNA) in sap.

Traditional methods of insect hemolymph collection, such as severing a leg, were not successful with whiteflies and did not cause release of hemolymph. Piercing the abdomen did cause bleeding; however, this method was abandoned because the digestive system was fragile, easily damaged, and resulted in the release of virus into the hemolymph samples. Removal of the hindwing from the thorax proved to be optimal for inducing hemolymph bleeding without causing damage to the digestive system. Even though it is considered unlikely, we are examining the possibility that fat body tissue contains detectable virus (39) that could, at times, be a source of viral DNA, inadvertently contaminating hemolymph samples and resulting in misinterpretation of PCR results.

Passage of virus from whitefly vector gut into hemolymph occurred shortly after sap ingestion was initiated, and virus DNA was detectable in hemolymph of whiteflies that were given an AAP as brief as $2 \mathrm{~h}$, despite a required minimum latent period of about 6 to $8 \mathrm{~h}$. In the nonvector, geminivirus was also ingested after a 2-h AAP, but virus DNA was not present in hemolymph fractions, indicating that detectable levels of virus did not cross the gut-hemocoel interface. Alternatively, geminivirus may have crossed the digestive system epitheia at levels below detection threshold, or, if virus did cross this membrane, it may have been rapidly degraded in nonvector hemolymph. These data suggest that the rate-limiting step may occur between virus entry into hemolymph and transmission or at the point of passage across the gut-hemocoel interface.

The absence of SLCV-AZ DNA in hemolymph and saliva of the nonvector whitefly, but its presence in the vector fractions, support the prediction that geminiviruses are circulative in their vector. Thus, the pathway appears to have certain features in common with other well-studied circulative plant virus-vector systems (30). Whitefly-mediated transmission also appears to have several unique characteristics. We provide evidence of a transmission pathway for geminiviruses in the vector that involves ingestion of virions with the phloem sap through the stylet food canal that is contiguous with the alimentary canal $(18,32,33,39)$. Geminiviruses probably exit the digestive system by crossing the gut epithelia, at an asyet-unidentified site, and enter the hemolymph for passage to the salivary glands. A recent study by Hunter et al. (35) proposes that begomoviruses enter the hemocoel by moving across the filter chamber and anterior midgut epithelia.

Finally, we conclude that the digestive system epithelia, or an as-yet-unknown tissue(s) in the nonvector, constitutes an effective barrier(s) to the passage of geminivirus across the gut to the hemocoel, rendering the greenhouse whitefly incapable of vectoring geminiviruses. This is despite a natural, long-standing association with many of the same plants that serve as hosts of $B$. tabaci, its localized phloem-feeding in planta, in a niche shared by both $B$. tabaci and geminiviruses and despite an ability to ingest geminivirus from this site in infected plants. Accordingly, the digestive system epithelia of $B$. tabaci may provide important sites of binding specificity or receptors that facilitate passage of virions across digestive system cells, permitting virus access to the hemocoel. Unlike luteovirus-aphid specificity, WFT geminiviruses appear unable to cross the gut membrane barrier of this nonvector, whereas nontransmissible luteoviruses have been shown to cross this barrier and then been unable to gain entry past the plasma membrane of the accessory salivary glands. In both systems, however, successful acquisition of virus appears to require mobility of virus to the salivary glands, in the hemolymph, and entry into the specialized cells of the vector salivary system.

\section{ACKNOWLEDGMENTS}

This research was supported by the NRI-USDA under award \#389110G-25-511. Initial studies toward this project were generously supported through a grant from E. I. Dupont \& de Nemours Company, Newark, DE. We thank A. Idris, D. Rogan, and R. Caballero for their technical assistance.

\section{LITERATURE CITED}

1. Azzam, O., Frazer, J., De La Rosa, D., Beaver, J. S., Ahlquist, P., and Maxwell, D. P. 1994. Whitefly transmission and efficient ssDNA accumulation of bean golden mosaic geminivirus require functional coat protein. Virology 204:289-296.

2. Bedford, I. D., Markham, P. J., Brown, J. K., and Rosell, R. C. 1994. Geminivirus transmission and biological characterization of whitefly (Bemisia tabaci) biotypes from different geographic regions. Ann. Appl. Biol. 125:311-325.

3. Bellows, Jr., T. S., Perring, T. M., Gill, R. J., and Headrick, D. H. 1994. Description of a species of Bemisia (Homoptera: Aleyrodidae) infesting North American agriculture. Ann. Entomol. Soc. Am. 87:195-206.

4. Bird, J. 1957. A whitefly-transmitted mosaic of Jatropha gossypifolia. Agric. Exp. Stn. Univ. Puerto Rico 22:1-35.

5. Bird, J., and Maramorosch, K. 1978. Viruses and virus diseases associated with whiteflies. Adv. Virus Res. 22:55-110.

6. Briddon, R. W., Pinner, M. S., Stanley, J., and Markham, P. G. 1990. Geminivirus coat protein gene replacement alters insect specificity. Virology 177:85-94.

7. Brown, J. K. 1990. An update on the whitefly-transmitted geminiviruses in the Americas and the Caribbean basin. FAO (Food Agric. Organ U.N.) Bull. 39:5-23.

8. Brown, J. K. 1994. A global position paper: The status of Bemisia tabaci Genn. as a pest and vector in world agroecosystems. FAO (Food Agric. Organ U.N.) Plant Prot. Bull. 42:3-32.

9. Brown, J. K., and Bird, J. 1992. Whitefly-transmitted geminiviruses and associated disorders in the Americas and the Caribbean Basin. Plant Dis. 76:220-225.

10. Brown, J. K., Bird, J., Frohlich, D. R., Rosell, R. C., Bedford, I. D., and Markham, P. G. 1996. The relevance of variability within the Bemisia tabaci species complex to epidemics caused by subgroup III geminiviruses. Pages 69-76 in: Bemisia '95: Taxonomy, Biology, Damage, Control and Management. D. Gerling and R. T. Meyers, eds. Intercept Publications, Wimborne, United Kingdom.

11. Brown, J. K., Frohlich, D. R., and Rosell, R. C. 1995. The sweetpotato/silverleaf whiteflies: Biotypes of Bemisia tabaci Genn., or a species complex? Annu. Rev. Entomol. 40:511-534.

12. Brown, J. K., and Nelson, M. R. 1986. Whitefly-borne viruses of melons and lettuce in Arizona. Phytopathology 76:236-239.

13. Brown, J. K., and Nelson, M. R. 1987. Host range and vector relationships of cotton leaf crumple virus. Plant Dis. 71:522-524.

14. Brown, J. K., and Nelson, M. R. 1988. Transmission, host range, and virus-vector relationships of chino del tomate virus, a whitefly-transmitted geminivirus from Sinaloa, Mexico. Plant Dis. 72:866-869.

15. Brown, J. K., and Nelson, M. R. 1989. Characterisation of watermelon curly mottle virus, a geminivirus distinct from squash leaf curl virus. Ann. Appl. Biol. 115:243-252.

16. Brown, J. K., and Ryan, R. 1991. High velocity microprojectile mediated 
transmission of whitefly-transmitted geminivirus DNA or purified virions to intact plants. (Abstr.) Phytopathology 81:1217.

17. Byrne, D. N., and Bellows, T. S. 1991. Whitefly biology. Annu. Rev. Entomol. 36:431-457.

18. Cicero, J. M., Hiebert, E., and Webb, S. E. 1995. The alimentary canal of Bemisia tabaci (Genn.) and Trialeurodes abutilonea (Hald.) (Aleyrodidae: Sternorhynchi: Homoptera), histology, ultrastructure, and correlations to function. Zoomorphology 115:31-39.

19. Cock, M. J. W. 1986. Bemisia tabaci-A literature survey on the cotton whitefly with an annotated bibliography. FAO/CAB, Ascot, United Kingdom.

20. Cohen, S., Duffus, J. E., Larsen, R. C., Liu, H. Y., and Flock, R. A. 1983. Purification, serology, and vector relationships of squash leaf curl virus, a whitefly-transmitted geminivirus. Phytopathology 73:1669-1673.

21. Cohen, S., Duffus, J. E., and Liu, H. Y. 1989. Acquisition, interference, and retention of cucurbit leaf curl viruses in whiteflies. Phytopathology 79:109-113.

22. Cohen, S., and Nitzany, F. E. 1966. Transmission and host range of the tomato yellow leaf curl virus. Phytopathology 56:1127-1131.

23. Costa, A. S. 1969. Whiteflies as vectors. Pages 27-49 in: Viruses, Vectors and Vegetation. K. Maramorosch, ed. John Wiley \& Sons, New York

24. Costa, A. S. 1976. Whitefly-transmitted plant diseases. Annu. Rev. Phytopathol. 14:429-449.

25. Costa, H. S., and Brown, J. K. 1991. Variation in biological characteristics and in esterase patterns among populations of Bemisia tabaci (Genn.) and the association of one population with silverleaf symptom development. Entomol. Exp. Appl. 61:211-219.

26. Costa, H. S., Henneberry, T. J., and Toscano, N. C. 1997. Effects of antibacterial materials on Bemisia argentifolii (Homoptera:Aleyrodidae) oviposition, growth, survival and sex ratio. J. Econ. Entomol. 90:333-339.

27. Deng, D., McGrath, P. F., Robinson, D. J., and Harrison, B. D. 1994. Detection and differentiation of whitefly-transmitted geminiviruses in plants and vector insects by the polymerase chain reaction with degenerate primers. Ann. Appl. Biol. 125:327-336.

28. Duffus, J. E. 1987. Whitefly transmission of plant viruses. Pages 73-91 in: Current Topics in Vector Research. K. F. Harris, ed. Springer-Verlag, New York.

29. Ghanim, M., Morin, S., Zeidan, M., and Czosnek, H. 1998. Evidence for transovarial transmission of tomato yellow leaf curl virus by its vector, the whitefly Bemisia tabaci. Virology 240:295-303.

30. Gildow, F. E. 1987. Virus-membrane interactions involved in circulative transmission of luteoviruses by aphids. Curr. Topics Vector Res. 4:93-120.

31. Goodman, R. M. 1981. Geminiviruses. J. Gen. Virol. 54:9-21.

32. Harris, K. F., Pesic-Van Esbroeck, Z., and Duffus, J. E. 1996. Anatomy of a virus vector. Pages 289-318 in: Bemisia '95: Taxonomy, Biology, Damage, Control and Management. D. Gerling and R. T. Meyers, eds.
Intercept Publications, Wimborne, United Kingdom.

33. Harris, K. F., Pesic-Van Esbroeck, Z., and Duffus, J. E. 1996. Morphology of the sweet potato whitefly, Bemisia tabaci (Homoptera, Aleyrodidae) relative to virus transmission. Zoomorphology 116:143-156.

34. Harrison, B. D. 1985. Advances in geminivirus research. Annu. Rev. Phytopathol. 23:55-82.

35. Hunter, W. B., Hiebert, E., Webb, S. E., Tsai, J. H., and Polston, J. E. 1998. Location of geminiviruses in the whitefly Bemisia tabaci (Homoptera: Aleyrodidae). Plant Dis. 82:1147-1151.

36. Lazarowitz, S. G. 1992. Geminiviruses: Genome structure and gene function. Crit. Rev. Plant Sci. 11:327-349.

37. Lazarowitz, S. G., and Lazdins, I. B. 1991. Infectivity and complete nucleotide sequence of the cloned genomic components of a bipartite squash leaf curl geminivirus with a broad host range phenotype. Virology 180:58-69.

38. Navot, N., Zeidan, M., Pichersky, E., Zamir, D., and Czosnek, H. 1992. Use of polymerase chain reaction to amplify tomato yellow leaf curl virus DNA from infected plants and viruliferous whiteflies. Phytopathology 82:1199-1202.

39. Pesic-Van Esbroeck, Z., Harris, K. F., and Duffus, J. E. 1995. Bemisiageminivirus immunocytochemistry. Pages 89-92 in: Advances in Vegetable Virus Research. Proc. Int. Conf. Virus Dis. Vegetables., 8th. Prague.

40. Polston, J. E., Al-Musa, A., Perring, T. M., and Dodds, J. A. 1990. Association of the nucleic acid of squash leaf curl geminivirus with the whitefly Bemisia tabaci. Phytopathology 80:850-856.

41. Rojas, M. R., Gilbertson, R. L., Russell, D. R., and Maxwell, D. P. 1993. Use of degenerate primers in the polymerase chain reaction to detect whitefly-transmitted geminiviruses. Plant Dis. 77:340-347.

42. Rosell, R. C., Torres-Jerez, I., and Brown, J. K. 1996. Monitoring geminivirus acquisition and transmission by whiteflies in artificial feeding chambers using polymerase chain reaction. Page 481 in: Proc. Int. Congr. Entomol., 20th. Firenze, Italy.

43. Rosell, R. C., Torres-Jerez, I., and Brown, J. K. 1997. Temporal monitoring of geminivirus movement into whitefly hemolymph using polymerase chain reaction (PCR). Page 99 in: Silverleaf whitefly (formerly sweetpotato whitefly, strain B): 1997 Supplement to the 5-year National Research and Action Plan-Fifth Annual Review. USDA-ARS, San Diego, CA.

44. Russell, L. M. 1957. Synonyms of Bemisia tabaci (Gennadius) (Homoptera: Aleyrodidae). Bull. Brooklyn Entomol. Soc. 52:122-123.

45. Separovic, E., and Nadin-Davis, S. A. 1994. Secondary structure within PCR target sequences may facilitate heteroduplex production. PCR Methods Appl. 3:248.

46. Wyatt, S. D., and Brown, J. K. 1996. Detection of subgroup III geminivirus isolated in leaf extracts by degenerate primers and polymerase chain reaction. Phytopathology 86:1288-1293. 